JE, Aguilera-Galaviz LA, Aceves Medina MC. // European Journal of Paediatric Dentistry. - 2018. - № 19(2) - P.119-126.

6. Ismail AF. Oral health of children with type 1 diabetes mellitus: A systematic review. / Ismail AF, Mcgrathb CP, Yiu KYC. // Diabetes Research and Clinical Practice. - 2015. - № 108(3) - P. 369-381.

7. Kuźmiuk A. Importance of dental care to maintain oral health of children and youth with type 1 diabetes. / Kuźmiuk A, Marczuk-Kolada G, Łuczaj-Cepowicz E, Obidzńska M, Chorzewska E, Wasilczuk U, Kierklo A, Szajda SD. // Medycyna Pracy. - 2018. - № 69(1) - P. 37-44.

8. Punthakee Z. Definition, Classification and Diagnosis of Diabetes, Prediabetes and Metabolic Syndrome. / Punthakee Z, Goldenberg R, Katz P. // Canadian Journal of Diabetes. - 2018 - № 42(1) - P. 10-15.

9. Rafatjou R. Dental Health Status and Hygiene in Children and Adolescents with Type 1 Diabetes Mellitus. / Rafatjou R, Razavi Z, Tayebi S, Khalili M, Farhadian M. // Journal of Research in Health Sciences. - 2016- № 16(3) - P. 122-126.

DOI https://doi.org/10.30525/978-9934-588-81-5-1.39

\title{
АЛГОРИТМ ТЕЛЕФОННИХ КОНСУЛЬТАЦЙ СІМЕЙНОГО ЛІКАРЯ В УМОВАХ ПАНДЕМІЇ COVID 19
}

\author{
Матейко Г. Б. \\ доктор медичних наук, професор, \\ завідувач кафедри дитячих інфекиійних хвороб \\ Івано-Франківський національний медичний університет \\ Антонюк Л. В. \\ асистент кафедри дитячих інфекиійних хвороб \\ Івано-Франківський національний медичний університет \\ Глушко У. А. \\ асистент кафедри дитячих інфекиійних хвороб \\ Івано-Франківський національний медичний університет \\ м. Івано-Франківськ, Украӥна
}

Професіоналізм лікаря визначається не тільки тим, наскільки добре він знає етіологію і патогенез хвороби, методи ії діагностики та лікування, але і його вмінням консультувати, тобто спілкуватися, вчити, радити. Уміння лікаря спілкуватися визначає його взаємини з хворим - 
тільки завоювавши довіру хворого, можна отримати всю необхідну інформацію, зібрати детальний анамнез хвороби, пояснити, що від нього вимагається в процесі лікування. Досвідчений фахівець викладає свої думки так, щоб вони були доступні для хворого, не породжували тривогу, викликали довіру, вселяли надію на успіх лікування [1].

Успіх лікаря при наданні консультацій залежить від багатьох вмінь. Перш за все, це вміння слухати. Немає нічого важливішого за вміння слухати свого співрозмовника. Вміння слухати - необхідна умова спілкування. Це не тільки здатність чути слова, а й розуміти їх зміст, сприймати емоційне забарвлення мови. Слухають не тільки вухами, слухають очима, розумом, серцем - усією душею. Людина не просто сприймає звук - слова, але й почуття, якими вони супроводжуються, будять уяву, емоції. Найважливіше можна передати інтонацією, жестом, мімікою.

Вміння слухати включає: сприйняття інформації, сприйняття почуттів, співчуття до співрозмовника, аналіз отриманої інформації. Слухати хворого треба уважно, не перебиваючи. При необхідності робити навідні зауваження: «ви чимось засмучені сьогодні..», «ви засмучені через чоловіка...», «здається, трапилося щось серйозне...», «ви хочете сказати, що...». Вміння слухати не тільки говорить про поважне ставлення до хворого, але і дозволяє з'ясувати справжню причину звернення до лікаря.

Не менш важливими є принципи спілкування: говорити доступною мовою; не зловживати медичними термінами; давати тільки чіткі інструкції; уникати двозначностей; не обіцяти неможливого; проінформувати хворого-його рішення мають бути осмисленими; перевірити чи правильно він зрозумівлікаря; обов'язково повторювати, якщо є відчуття, що хворий не все зрозумів; впевнитись, що у хворого не залишилось невирішених питань; коли необхідно, направити хворого до іншого фахівця.

Лікар повинен володіти здатністю до співпереживання, дбайливістю, шанобливим ставленням до хворого, стурбованістюйого долею, зберігати лікарську таємницю, довіру хворому, чуйність, проникливість, сумлінність, відповідальність, компетентність.

Комунікативна компетентність - професійно значуща якість лікаря, необхідна при постійному і тривалому спілкуванні з хворими, їхніми родичами. Уміння спілкуватися, встановлювати й розвивати взаємини 3 людьми багато в чому залежить від професійного успіху лікаря. Хороший психологічний контакт з хворим допомагає точніше зібрати анамнез, отримати більш повне і глибоке уявлення про хворого. Уміння спілкуватися забезпечує взаєморозуміння, довіру у відносинах, ефективністьу вирішенні поставлених завдань. Якщо пацієнт довіряє своєму лікареві, несумнівається у правильності діагностики і 
адекватності терапії, він буде виконувати призначення, пройде всі необхідні діагностичні і терапевтичні процедури. При відсутності психологічного контакту пацієнт може недотримуватись лікарських рекомендацій та призначень, проконсультується в інших лікарів чи у своїх знайомих, займеться самолікуванням, звернеться до представників альтернативної медицини [2].

Комунікативна компетентність передбачає не тільки наявність певних психологічних знань (про типи особистості, способи переживання i реагування на стрес різних людей залежно від типу темпераменту, про специфіку зв'язку між типами статури і особливостями психічного складу особистості), але і сформованість деяких спеціальних навичок: вміння встановлювати контакт, слухати, володіти невербальною мовою комунікації, будувати бесіду, формулювати питання. Важливим є володіння лікарем власними емоціями, здатність зберігати впевненість, контролювати свої реакції і поведінку в цілому.

Адекватна комунікація передбачає правильне розуміння хворого i відповідне реагування на його поведінку. Незалежно від того, у якому душевному стані перебуває пацієнт, відчуває він гнів або розчарування, занепокоєння, тривогу або відчай, лікар повинен вміти з ним взаємодіяти, адекватно будувати відносини, які допоможуть вирішити професійні завдання. У зв'язку з цим професійно значущою якістю медичного працівника є комунікативна толерантність - терпимість, поблажливість. Комунікативна толерантність показує, якою мірою лікар переносить суб’єктивно небажані, неприйнятні для нього індивідуальні особливості пацієнтів, негативні якості, засуджувані вчинки, звички, чужі стилі поведінки і стереотипи мислення.

Хворий може викликати різні почуття, подобатися або не подобатись, бути приємним або неприємним лікарю, але в будь-якому випадку психологічна підготовка останнього повинна допомогти впоратися 3 ситуацією, запобігти конфлікту або виникненню неформальних відносин, коли замість рольової структури «лікар - хворий» виникають відносини дружби, психологічної близькості, залежності, симпатії. Комунікативна компетентність у професійній діяльності лікаря означає вміння не тільки психологічно правильно будувати відносини з хворим, але і здатність у процесі цих відносин залишатися в рамках професійної ролі.

Для успішного дистанційного спостереження лікарю необхідно:

- повідомити хворому номер свого телефона, не уникати телефонних розмов із ним;

- регулярно повідомляти хворому результати аналізів та інших досліджень; 
- контролювати виконання призначень;

- при спізненні або відтермінуванні консультації попередити хворого по телефону;

- при необхідності або неефективності лікування направити хворого до іншого фахівця;

- коли потрібно, наполягати на госпіталізації [3].

Телефонні консультації як новий спосіб комунікаціції оцінюються в юридичному аспекті як недостатній доказ правоти. Тому лікар повинен задокументувати таку консультацію, а в деяких випадках записати іiі після отримання відповідного дозволу пацієнта та письмового свого зобов'язання про дотримання конфіденційності.

За сучасних умов реформування медицини та епідеміологічної ситуації в Україні з приводу COVID-19 дистанційні консультації доцільно ввести в щоденний об'єм професійної роботи лікаря 3 відповідною оплатою такої послуги, оскільки їх роль в даний час, коли необхідно обмежити виїзди лікарів на дім, є дуже високою. Такі консультації повинні задовільнити всі потреби пацієнта, який має отримати відповіді на всі запитання, вчасно зрозуміти що з ним відбувається і при необхідності негайно звернутись за медичною допомогою на «103» для госпіталізації на підставі відстежуваних симптомів.

\section{Література:}

1. WHO. Novel Coronavirus (2019-nCoV) Situation Report-22 [EB/OL]. (2020-02-11)[2020-03-15] URL: https://www.who.int/ emergencies/diseases/novel-coronavirus-2019/situation-reports/

2. National Clinical Research Center for Infectious Diseases, State Key Laboratory for Diagnosis and Treatment of Infectious Diseases. Expert Consensus on Novel Coronavirus Pneumonia Treated with Artificial Liver Blood Purification System. Chinese Journal of Clinical Infectious Diseases. 2020. № 13. (in Chinese) doi:10.3760/cma.j.issn.1674-2397.2020.0003.

3. Bureau of Disease Control and Prevention, National Health Commission of the People's Republic of China. Novel coronavirus infection pneumonia is included in the management of notifiable infectious diseases [EB/OL]. (in Chinese) (2020-01-20) [2020-02-15]. URL: http://www.nhc.gov.cn/jkj/s7915/202001/e4e2d5e6f01147e0a8d f3f6701d49f33.shtml 